\title{
EFFECT OF IRRIGATION, NITROGEN AND ORGANIC FERTILIZATION ON YIELD AND NUTRIENT CONTENTS OF ZEA MAIZE CROP \\ El-Hamdi, Kh. H. ${ }^{*}$ H. A. Meshref*; S. A. Abdel-Hafez ${ }^{* *}$ and Gh. Sh. El-Atawy ${ }^{\star *}$ \\ * Soil Sci. Dept. Fac. of Agric. Mansoura Univ., Egypt. \\ ${ }^{* *}$ Soil Water and Environment Res. Ins. Res. Center, Giza, Egypt.
}

\begin{abstract}
A field experiment was carried out at El-Roba village, Baltim, Kafr El- Sheikh Governorate, Egypt during two consecutive growing summer seasons 2004 and 2005 to study the effect of irrigation regimes, organic manure and source and levels of nitrogen fertilizers on zea maize yield and nutrient contents.

The obtained results could be summarized as follows:

The highest values of $\mathrm{N}$ concentration in ear leaf $(1.89 \%)$ in the $1^{\text {st }}$ season as well as $\mathrm{P}$ concentration ( 0.323 and $0.319 \%$ ) and $\mathrm{K}$ concentration ( 2.62 and $2.67 \%$ ) in both seasons were obtained from zea maize plants irrigated at 1.3 evaporation pan coefficient with applying $10 \mathrm{~m}^{3}$ chicken manure $\mathrm{fed}^{-1}$ and fertilized with enciabeen at $320 \mathrm{~kg} \mathrm{~N}$ fed. ${ }^{-1}$.

The highest values of ear diameter $(5.48 \mathrm{~cm})$ and $\mathrm{N}$ concentration $(1.94 \%)$ in the $2^{\text {nd }}$ season and grain yield (28.69 and 30.1 ardab fed. $\left.{ }^{-1}\right)$ in both seasons were obtained from zea maize plants irrigated at 1.3 evaporation pan coefficient, fertilized with $10 \mathrm{~m}^{3}$ chicken manure fed. ${ }^{-1}$ and fertilized with urea at $160 \mathrm{~kg} \mathrm{~N}$ fed.- ${ }^{-1}$.

The highest values of ear diameter $(4.5 \mathrm{~cm})$ in the $1^{\text {st }}$ season and 100 -grain weight ( 32.91 and $33.3 \mathrm{~g})$ in the $1^{\text {st }}$ and $2^{\text {nd }}$ seasons were obtained from zea maize plants irrigated at 1.3 evaporation pan coefficient, fertilized with $10 \mathrm{~m}^{3}$ chicken manure fed. ${ }^{-1}$ and fertilized with urea at $240 \mathrm{~kg} \mathrm{~N}_{\text {fed. }}{ }^{-1}$.

From these results, it could be concluded that the application of irrigation water at 1.3 evaporation pan coefficient could be recommended with zea maize for high production under North Delta conditions.

Keywords: Irrigation, $\mathrm{N}$ fertilization, organic fertilization, nutrient contents and zea maize.

\section{INTRODUCTION}

Water is very important for life in both the biochemical and biophysical synthesis and its influences are both internal and environmental. Water is often the primary limiting factor for maize production. The idea of applying too much water in irrigation to achieve maximum crop yield is not always correct, where, it causes losses of water and fertilizers through leaching. Nitrogen fertilization increased maize yield, this increase may reflect the high response of maize plants to nitrogen fertilizers and consequently improvement of plant growth parameters. Application of organic manure improved soil organic matter contents and soil physical and chemical properties through providing the soil with macro and micronutrients as well as improving soil structure, Othman-Sanaa et al. (2005). Zea maize is one of the most important cereal crops in Egypt for human consumption and animal feeding.
\end{abstract}




\section{El-Hamdi, Kh. H. et al.}

Grain yield, 100-grain weight and ear diameter of zea maize were increased with increasing available soil moisture (Karam et al., 2002; AbdelMawly and Zanouny, 2005 and Nofal-Fatma et al., 2005). Omran (2005) indicated that increment of grain yield of zea maize might be attributed to positive effect of more available moisture at grain filling which increase the starch contents and organic compounds in maize plants. El-Nagar (2003) indicated that increasing soil moisture increases the mobility of $\mathrm{N}, \mathrm{P}$ and $\mathrm{K}$, where, the rate of solubility and extent of $\mathrm{N}, \mathrm{P}$ and $\mathrm{K}$ migration increased with increasing soil moisture content.

Applying $10 \mathrm{~m}^{3}$ fed. $^{-1}$ of chicken manure or rice straw compost increased maize grain yield compared the control treatment (without organic manure). This increment may be attributed to the improving action of organic matter on the physical and chemical properties of soil. (Nofal-Fatma et al., 2005). Also, organic manure contains microorganisms which fix in and release phytohormones, which stimulate plant growth, $\mathrm{N}, \mathrm{P}$ and $\mathrm{K}$ contents. (Othman-Sanaa et al., 2005).

Grain yield, 100-grain weight and NPK content of zea maize was gradually increased with increasing nitrogen fertilization levels from 0 up to $160 \mathrm{~kg} \mathrm{~N}$ fed. ${ }^{-1}$ urea in both seasons. ( Nofal-Fatma and Mobarak, 2003 and Nofal-Fatma et al., 2005).

Therefore, this investigation aimed to study the effect of irrigation regimes, organic manure and source and levels of nitrogen fertilizers on zea maize yield and nutrient contents of it.

\section{MATERIALS AND METHODS}

\section{Experimental treatments :}

The experimental design was split-split-split plot, where the two sources of nitrogen fertilizers (urea and enciabeen -slow release fertilizer-) were assigned in the main-plots, three irrigation regimes (1.3, 1.0 and 0.7 evaporation pan coefficient) were situated in the sub-plots, the organic manure was assigned in the sub-sub plots (chicken manure at $10 \mathrm{~m}^{3}$ fed. ${ }^{-1}$, compost at $10 \mathrm{~m}^{3}$ fed. ${ }^{-1}$ and non O.M.) and the five $\mathrm{N}$ fertilizer levels $(0,80$, 160,240 and $320 \mathrm{~kg} \mathrm{~N}$ fed.-1) were situated in the sub-sub-sub plots. In each of the two seasons, calcium super phosphate $\left(15.5 \% \mathrm{P}_{2} \mathrm{O}_{5}\right)$ was applied at the rate of $200 \mathrm{~kg}$ fed. ${ }^{-1}$ in the last season to tomato crop during the field preparation, while potassium sulphate $\left(48 \% \mathrm{~K}_{2} \mathrm{O}\right)$ was applied at the rate of $100 \mathrm{~kg}$ fed.- ${ }^{-1} 6$ weeks after tomato transplanting. The mechanical and chemical analyses of experimental soil in both seasons are given in Table 1. The chemical analyses of chicken manure and rice straw compost are shown in Table 2.

The chemical analysis of the irrigation water is given in Table 3 .

Every experimental unit area was $40 \mathrm{~m}^{2}(8 \times 5 \mathrm{~m})$, which contained seven ridges of $8 \mathrm{~m}$ length and $70 \mathrm{~cm}$ width. Zea maiz seeds were planted in hills of $30 \mathrm{~cm}$ apart.

Plant samples: five ear leaves of zea maize per experimental unit were taken and dried at $70^{\circ} \mathrm{C}$, ground and digested using wet ashing method by a mixture concentrated $\mathrm{H}_{2} \mathrm{SO}_{4}+\mathrm{HClO}_{4}(10: 1)$ according to Chpman and Pratt 
(1961) to determine ear leaf content of nitrogen, phosphorus and potassium. $\mathrm{N}$ concentration was determined using modified micro - kjeldahl method ( Page et al., 1984). (1962).

Phosphorus was calorimetrically determined by Murphy and Riley

Potassium was determined using flamphotometer (Jackson, 1973).

\section{Irrigation treatments:}

Potential evapotranspiration by evaporation class A Pan was used. Prevailing weather data of the previous three years of Seedy Salem, Kafr ElSheikh Governorate were used to estimate the potential evapotranspiration as daily average during the growing seasons of zea maize plants. Irrigation was applied according to the daily record of the evaporation pan and the crop was irrigated when the water balance reached zero. Application of irrigation regime treatments started after life watering.

Table 1: Mechanical and chemical analyses of soil during both seasons of experimentation:

\begin{tabular}{|c|c|c|c|c|c|c|c|c|c|c|c|c|c|c|}
\hline \multirow{3}{*}{ Season } & \multicolumn{4}{|c|}{ Physical properties } & \multicolumn{10}{|c|}{ Chemical properties ( soil paste) } \\
\hline & \multirow[t]{2}{*}{ Sand } & \multirow[t]{2}{*}{ Silt } & \multirow{2}{*}{ Clay } & \multirow[t]{2}{*}{ Texture } & \multirow{2}{*}{$\begin{array}{l}\mathrm{EC} \\
\mathrm{dSm}^{-1}\end{array}$} & \multirow[t]{2}{*}{$\mathrm{pH}$} & \multicolumn{4}{|c|}{$\begin{array}{l}\text { Soluble cations } \\
\left(\text { meq }^{-1}\right)\end{array}$} & \multicolumn{4}{|c|}{$\begin{array}{c}\text { Soluble anions } \\
\left(\mathrm{meq} \mathrm{L}^{-1}\right)\end{array}$} \\
\hline & & & & & & & $\mathrm{Ca}^{++}$ & $\mathbf{M g}^{++}$ & $\mathrm{Na}^{+}$ & $\mathbf{K}^{+}$ & $\mathrm{CO}_{3}^{--}$ & $\mathrm{HCO}_{3}$ & $\mathrm{Cl}^{-}$ & $\mathrm{SO}_{4}^{--}$ \\
\hline $\begin{array}{l}2003 / \\
2004\end{array}$ & 72 & 15 & 13 & $\begin{array}{l}\text { Sandy } \\
\text { loam }\end{array}$ & 1.87 & 7.8 & 5.4 & 2.7 & 9.1 & 1.3 & -- & 2.34 & 7.93 & 8.23 \\
\hline $\begin{array}{l}2004 / \\
2005\end{array}$ & 73 & 14 & 13 & $\begin{array}{l}\text { Sandy } \\
\text { loam }\end{array}$ & 1.92 & 7.7 & 5.8 & 3.1 & 8.6 & 1.7 & -- & 2.53 & 8.17 & 8.50 \\
\hline
\end{tabular}

Table 2: Chicken manure and rice straw compost analyses

\begin{tabular}{|l|c|c|c|c|}
\hline \multirow{2}{*}{ Property } & \multicolumn{2}{|c|}{ Rice straw compost } & \multicolumn{2}{c|}{ Chicken manure } \\
\cline { 2 - 5 } & $\mathbf{1}^{\text {st }}$ year & $\mathbf{2}^{\text {nd }}$ year & $\mathbf{1}^{\text {st }}$ year & $\mathbf{2}^{\text {nd }}$ year \\
\hline Organic matter & 32.71 & 32.62 & 58.80 & 60.00 \\
\hline Moisture content \% & 25.89 & 26.1 & 15.11 & 15.64 \\
\hline $\mathrm{pH}$ & 7.43 & 7.49 & 8.13 & 8.21 \\
\hline EC $\left(\mathrm{dS} \mathrm{m}^{-1}\right)$ & 8.12 & 8.61 & 4.65 & 4.78 \\
\hline Total N \% & 3.93 & 3.70 & 3.56 & 3.76 \\
\hline Total P \% & 0.91 & 0.90 & 2.11 & 2.23 \\
\hline Total K \% & 0.63 & 0.60 & 1.57 & 1.38 \\
\hline C/N Ratio & 18.6 & 19.3 & 15 & 14 \\
\hline
\end{tabular}

\section{Nitrogen fertilization:}

The treatments of enciabeen: Zea maize seeds were planted after tomato plants fertilized with enciabeen to measure the residual effect of slow release nitrogen fertilizer (enciabeen), while, the treatments of urea, zea maize plants fertilized with urea in the same growth.

Table 3: Some characteristics of irrigation water

\begin{tabular}{|c|c|c|c|c|c|c|c|c|c|c|c|}
\hline \multicolumn{4}{|c|}{ Cations meq L-1 } & \multicolumn{4}{|c|}{ Anions meq $\mathrm{L}^{-1}$} & \multirow[b]{2}{*}{ pH } & \multirow{2}{*}{$E C \mathrm{dSm}^{-1}$} & \multirow{2}{*}{ TSS } & \multirow{2}{*}{ SAR } \\
\hline $\mathrm{Ca}^{++}$ & $\mathrm{Mg}^{++}$ & $\mathrm{Na}^{+}$ & $\mathrm{K}^{+}$ & $\mathrm{CO}_{3}$ & $\mathrm{HCO}^{-}$ & $\mathrm{Cl}^{-}$ & $\mathrm{SO}_{4}^{--}$ & & & & \\
\hline 2.87 & 4.43 & 6.7 & 0.23 & --- & 4.3 & 4.6 & 5.23 & 7.5 & 1.4 & 910 & 3.51 \\
\hline
\end{tabular}




\section{RESULTS AND DISCUSSION}

\section{1- Yield and its component:}

\section{1-1: Ear diameter:}

The data listed in Table 4 reveal that ear diameter of maize was significantly affected by the application of organic manure and $\mathrm{N}$ fertilizer levels in both seasons and significantly affected by irrigation regimes and the source of $\mathrm{N}$ fertilizer in the $2^{\text {nd }}$ season, while, it not significantly affected by irrigation regimes and the source of nitrogen fertilizer in the $1^{\text {st }}$ season. The highest values of ear diameter as affected by irrigation regimes (4.25 and $4.24 \mathrm{~cm}$ ) resulted from zea maize plants irrigated at $1.3 \mathrm{ETp}$ in the $1^{\text {st }}$ and $2^{\text {nd }}$ seasons, respectively. This increase can be attributed to the significant role of available water in affecting ear diameter. These results accordance with those obtained by Nofal-Fatma et al. (2005) and Omran (2005).

The highest values of ear diameter as affected by organic manure $\left(4.25\right.$ and $4.46 \mathrm{~cm}$ ) obtained from fertilization with $10 \mathrm{~m}^{3}$ chicken manure fed. ${ }^{-1}$ in 2004 and 2005 seasons, respectively. Improving ear diameter by applying chicken manure was a reflection to the stimulatory effect of both treatments on vegetative growth and availability nutrients. These results agreed with those of El-Atawy (2007), Nofal-Fatma et al. (2005) and OthmanSanaa et al. (2005).

The highest value of ear diameter as affected by the source of $\mathrm{N}$ fertilizer in the $1^{\text {st }}$ season $(4.22 \mathrm{~cm})$ resulted with enciabeen, while, the highest value in the $2^{\text {nd }}$ season $(4.12 \mathrm{~cm})$ obtained with adding urea.

The data listed in Table 4 reveal that ear diameter of maize in the $1^{\text {st }}$ and $2^{\text {nd }}$ seasons increased significantly by increasing nitrogen application. The highest ear diameter in the $1^{\text {st }}$ season $(4.3 \mathrm{~cm})$ obtained by adding 240 $\mathrm{kg} \mathrm{N}$ fed $^{-1}$, while, the highest ear diameter in the $2^{\text {nd }}$ season $(4.34 \mathrm{~cm})$ resulted by adding $160 \mathrm{~kg} \mathrm{~N}$ fed. ${ }^{-1}$ The increase in ear diameter was resulted from the increase in vegetative growth. Similar results were obtained by Nofal-Fatma and Mobarak (2003) and Nofal-Fatma et al. (2005).

\section{1-2: 100-grain weight (g):}

The data presented in Table 4 indicate that 100-grain weight was not significantly affected by the source of nitrogen fertilizers, significantly affected by irrigation regimes and high significantly affected by organic manure and $\mathrm{N}$ fertilizer levels in both seasons. The highest values as affected by irrigation regimes $(29.7$ and $29.55 \mathrm{~g})$ obtained from irrigation at $1.3 \mathrm{ETp}$ in the $1^{\text {st }}$ and $2^{\text {nd }}$ seasons, respectively. It is evident that prolonging irrigation interval might have decreased soil moisture availability and hence might have reduced metabolites translocation to the developing grains.

These results accordance with those obtained by El-Atawy (2007), Mahdi and Yin (2003) and Nofal-Fatma et al. (2005). 
The highest values as affected by organic manure (29.93and $30.32 \mathrm{~g}$ ) obtained from adding $10 \mathrm{~m}^{3}$ chicken manure fed ${ }^{-1}$ in the $1^{\text {st }}$ and $2^{\text {nd }}$ seasons, respectively. The increments of 100-grain weight of maize, due to compost or chicken manure additions, may be attributed to the improving action of its fertilizers on the chemical and physical properties in the soil. The present results agree with those obtained by Hanna and El-Awag (2000) and NofalFatma et al. (2005).

Table 4: Effect of irrigation regimes, organic manure, source of $\mathrm{N}$ fertilizer and its levels and their interactions on the yield and its components of zea maize in 2004 and 2005 seasons.

\begin{tabular}{|c|c|c|c|c|c|c|}
\hline \multirow[t]{2}{*}{ Treatment } & \multicolumn{2}{|c|}{$\begin{array}{c}\text { Grain yield (ard. } \\
\text { fed. } .^{-1} \text { ) }\end{array}$} & \multicolumn{2}{|c|}{$\begin{array}{l}\text { 100-grain weight } \\
\text { (g) }\end{array}$} & \multicolumn{2}{|c|}{$\begin{array}{l}\text { Ear diameter } \\
(\mathbf{c m})\end{array}$} \\
\hline & 2004 & 2005 & 2004 & 2005 & 2004 & 2005 \\
\hline \multicolumn{7}{|c|}{ A: Source of $\mathbf{N}$ fertilizer: } \\
\hline 1 -Urea & 21.62 & 21.84 & 28.98 & 29.34 & 4.21 & 4.12 \\
\hline 2 -Enciabeen & 20.51 & 20.65 & 29.43 & 28.96 & 4.22 & 3.80 \\
\hline F. test & * & * & N.S. & N.S. & N.S. & * \\
\hline \multicolumn{7}{|c|}{ B : Irrigation regimes: } \\
\hline 1-1.3 Pan evaporation & 22.15 & 22.31 & 29.70 & 29.55 & 4.25 & 4.24 \\
\hline 2-1.0 Pan evaporation & 20.86 & 21.31 & 29.21 & 29.16 & 4.23 & 4.10 \\
\hline 3-0.7 Pan evaporation & 20.19 & 20.12 & 28.70 & 28.74 & 4.16 & 3.98 \\
\hline F. test & $\star \star *$ & 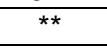 & * & * & N.S. & * \\
\hline L.S.D. at $5 \%$ & 0.376 & 0.285 & 0.371 & 0.215 & -- & 0.116 \\
\hline \multicolumn{7}{|c|}{ C : Organic manure : } \\
\hline 1-Chicken manure & 24.04 & 25.26 & 29.93 & 30.32 & 4.25 & 4.46 \\
\hline 2- Rice straw compost & 20.87 & 24.39 & 29.72 & 29.71 & 4.22 & 3.90 \\
\hline 3-Non organic manure & 18.29 & 18.39 & 27.95 & 27.43 & 4.16 & 3.85 \\
\hline F. test & ** & $* *$ & $\star \star$ & $\star *$ & $\star$ & $*$ \\
\hline L.S.D. at $5 \%$ & 1.054 & 0.746 & 0.095 & 0.216 & 0.026 & 0.038 \\
\hline \multicolumn{7}{|c|}{ D: Nitrogen fertilizer levels: } \\
\hline 1- $0 \mathrm{~N}$ (control) & 17.76 & 17.58 & 27.61 & 26.95 & 4.05 & 3.60 \\
\hline $2-80 \mathrm{~kg} \mathrm{~N} \mathrm{fed} .^{-1}$ & 20.17 & 20.44 & 28.75 & 28.30 & 4.17 & 4.00 \\
\hline 3-160 kg N fed..$^{-1}$ & 22.20 & 22.68 & 29.83 & 29.70 & 4.27 & 4.34 \\
\hline $4-240 \mathrm{~kg} \mathrm{~N}$ fed..$^{-1}$ & 22.62 & 22.78 & 30.42 & 30.63 & 4.30 & 4.31 \\
\hline $5-320 \mathrm{~kg} \mathrm{~N}$ fed..$^{-1}$ & 22.58 & 22.58 & 29.39 & 30.18 & 4.28 & 4.29 \\
\hline F. test & ** & ** & ** & ** & * & * \\
\hline L.S.D. at $5 \%$ & 0.029 & 0.047 & 0.268 & 0.165 & 0.012 & 0.016 \\
\hline \multicolumn{7}{|c|}{ Sig. Interaction : } \\
\hline$A \times B$ & ** & ** & ** & ** & ** & ** \\
\hline$A \times C$ & ** & ** & ** & ** & ** & ** \\
\hline$A \times D$ & ** & ** & ** & ** & ** & ** \\
\hline$B \times C$ & ** & ** & $\star \star *$ & ** & ** & ** \\
\hline$B \times D$ & *夫 & ** & ** & *夫 & *夫 & *夫 \\
\hline$C \times D$ & ** & ** & $\star *$ & ** & ** & ** \\
\hline$A \times B \times C \times D$ & ** & ** & ** & ** & ** & ** \\
\hline
\end{tabular}

These results show that zea maize plants which grown in enciabeen treatments resulted 100-grain weight not significantly difference about 


\section{El-Hamdi, Kh. H. et al.}

urea.This effect may be due to sequestering act of SRNF components formed during its decomposition and which would make soil elements get more available. These results accordance with those obtained by Abbady-Khadra et al. (2003) and El-Atawy (2007).

The highest values of 100 -grain weight as affected by $\mathrm{N}$ fertilizer levels $(30.42$ and $30.63 \mathrm{~g})$ obtained by fertilization with $240 \mathrm{~kg} \mathrm{~N}$ fed. ${ }^{-1}$ in both seasons. The increase in 100-grain weight might be due to the increase in the assimilation rates of translocated materials to the grains rather than the increase in number of grain per ear.

These results are in harmony with those obtained by El-Atawy (2007), Nofal-Fatma and Mobarak (2003) and Nofal-Fatma et al. (2005).

\section{1-3: Grain Yield (ard. fed.-1):}

The data listed in Table 4 indicate that grain yield of zea maize (ard. fed. ${ }^{-1}$ ) was high significantly affected by irrigation regimes, organic manure and $\mathrm{N}$ fertilizer levels, while, it significantly affected by the source of $\mathrm{N}$ fertilizer in both seasons.

The highest values as affected by irrigation regimes (22.12 and 22.31 ard.fed. ${ }^{-1}$ ) obtained from irrigation at 1.3 ETp in the $1^{\text {st }}$ and $2^{\text {nd }}$ seasons, respectively. This increment of grain yield of zea maize might be attributed to positive effect of more available moisture at grain filling which increase the starch contents and organic compounds in maize plants. These results are supported with those obtained by Karam et al. (2002), Mahdi and Yin (2003), Nofal-Fatma et al. (2005) and Omran (2005).

The highest values of grain yield as affected by organic manure $(24.04$ and 25.26 ard.fed. ${ }^{-1}$ ) in the $1^{\text {s }}$ and $2^{\text {nd }}$ seasons, respectively obtained from fertilization at $10 \mathrm{~m}^{3}$ chicken manure fed.-1. This increment of grain yield due to organic manure additions may be attributed to the improving action of organic matter on the physical and chemical properties of soil. These results accordance with those obtained by Hanna and El-Awag (2000), Nofal-Fatma et al. (2005) and Othman-Sanaa et al. (2005).

The fertilization of maize plants with urea increased grain yield by 5.4 and $5.8 \%$ only in 2004 and 2005 seasons, respectively compared those plants which grown at enciabeen treatments after tomato plants which fertilized in the last seasons at the same rates of $\mathrm{N}$ fertilizers. These results reveal that enciabeen (SRNF) had a significant effect on next crops which grown after aforetime essential crops, especially when SRNF are applied at high rates. SRNF may be available regular source for $\mathrm{N}$ supply. These results are in harmony with those obtained by Abbady-Khadra et al. (2003) and ElAtawy (2007).

Data listed in Table 4 reveal that grain yield of zea maize was high significantly in both two growing seasons. The highest values of grain yield as affected by the $\mathrm{N}$ fertilizer levels were $\left(22.62\right.$ and 22.78 ard.fed. $\left.{ }^{-1}\right)$ in the $1^{\text {st }}$ and $2^{\text {nd }}$ seasons, respectively, obtained by adding $240 \mathrm{~kg} \mathrm{~N}$ fed. ${ }^{-1}$. These results prove clearly the prominent role of $\mathrm{N}$ element for increasing grain yield. The effect of $\mathrm{N}$ fertilizer on grain yield is the outcome of its positive effect on grain yield components and plant growth parameters (Table 4). These results may be enhanced by those obtained by El-Nagar (2003); Nofal-

Fatma and Mobarak (2003) and Nofal-Fatma et al. (2005). 
2-Chemical content of zea maize plants:

Data in Table 5 reveal that N, P and $\mathrm{K}$ concentration in ear leaf of zea maize plants was significantly affected by irrigation regimes and high significantly affected by organic manure and nitrogen fertilizer levels in both seasons.

The highest values of $\mathrm{N}, \mathrm{P}$ and $\mathrm{K}$ Concentration as affected by irrigation regimes were ( 1.531 and $1.521 \%),(0.264$ and $0.262 \%)$ and $(2.117$ and $2.157 \%$ ) obtained from zea maize plants irrigated at 1.3 evaporation pan coefficient in both seasons, respectively. These results accordance with those obtained by El-Nagar (2003).

Table 5 : Effect of irrigation regimes, organic manure, source of $\mathrm{N}$ fertilizer and its levels and their interactions on N, P and $K$ concentration \% in zea maize leaves in 2004 and 2005 seasons.

\begin{tabular}{|c|c|c|c|c|c|c|}
\hline \multirow[b]{2}{*}{ Treatments } & \multicolumn{2}{|c|}{$\mathrm{N} \%$} & \multicolumn{2}{|c|}{ P \% } & \multirow[b]{2}{*}{$\begin{array}{c}1^{\text {st }} \\
\text { season }\end{array}$} & \multirow[b]{2}{*}{$\begin{array}{c}2^{\text {nd }} \\
\text { season }\end{array}$} \\
\hline & $\begin{array}{c}1^{\text {st }} \\
\text { season }\end{array}$ & $\begin{array}{c}2^{\text {nd }} \\
\text { season }\end{array}$ & $\begin{array}{c}1^{\text {st }} \\
\text { season }\end{array}$ & $\begin{array}{c}2^{\text {nd }} \\
\text { season }\end{array}$ & & \\
\hline \multicolumn{7}{|c|}{ A: Source of N Fertilizer: } \\
\hline 1 :Urea & 1.418 & 1.466 & 0.247 & 0.247 & 2.065 & 2.088 \\
\hline 2-Enciabeen & 1.500 & 1.468 & 0.266 & 0.262 & 2.081 & 2.086 \\
\hline F. test & * & N.S. & * & * & N.S. & N.S. \\
\hline \multicolumn{7}{|c|}{ B : Irrigation regimes: } \\
\hline 1-1.3 Pan evaporation & 1.531 & 1.521 & 0.264 & 0.262 & 2.117 & 2.157 \\
\hline 2-1.0 Pan evaporation & 1.430 & 1.460 & 0.258 & 0.253 & 2.060 & 2.088 \\
\hline 3-0.7 Pan evaporation & 1.415 & 1.420 & 0.248 & 0.248 & 2.042 & 2.015 \\
\hline F. test & * & * & * & * & * & * \\
\hline L.S.D. at $5 \%$ & 0.011 & 0.031 & 0.005 & 0.004 & 0.016 & 0.053 \\
\hline \multicolumn{7}{|c|}{ C : Organic manure : } \\
\hline 1-Chicken manure & 1.558 & 1.587 & 0.277 & 0.275 & 2.291 & 2.312 \\
\hline 2- Rice straw compost & 1.536 & 1.540 & 0.269 & 0.265 & 2.136 & 2.127 \\
\hline 3-Non organic manure & 1.281 & 1.275 & 0.224 & 0.224 & 1.791 & 1.820 \\
\hline F. test & ** & ** & ** & ** & ** & ** \\
\hline L.S.D. at $5 \%$ & 0.013 & 0.021 & 0.005 & 0.007 & 0.053 & 0.094 \\
\hline \multicolumn{7}{|c|}{ D: Nitrogen fertilizer levels: } \\
\hline 1- $0 \mathrm{~kg} \mathrm{~N}$ fed..$^{-1}$ (control ) & 1.242 & 1.250 & 0.212 & 0.215 & 1.558 & 1.605 \\
\hline $2-80 \quad \mathrm{~kg} \mathrm{~N} \mathrm{fed.}{ }^{-1}$ & 1.376 & 1.380 & 0.240 & 0.238 & 1.918 & 1.974 \\
\hline 3-160 kg N fed..$^{-1}$ & 1.528 & 1.554 & 0.282 & 0.267 & 2.225 & 2.197 \\
\hline $4-240 \mathrm{~kg} \mathrm{~N} \mathrm{fed.}{ }^{-1}$ & 1.567 & 1.576 & 0.279 & 0.277 & 2.318 & 2.307 \\
\hline $5-320 \mathrm{~kg} \mathrm{~N} \mathrm{fed}^{-1}$ & 1.580 & 1.578 & 0.270 & 0.276 & 2.350 & 2.353 \\
\hline F. test & $\star *$ & $* *$ & $\star *$ & $\star *$ & $\star *$ & ** \\
\hline L.S.D. at $5 \%$ & 0.007 & 0.001 & 0.002 & 0.001 & 0.026 & 0.031 \\
\hline \multicolumn{7}{|c|}{ Sig. Interaction : } \\
\hline$A \times B$ & ** & ** & ** & ** & ** & ** \\
\hline$A \times C$ & ** & ** & ** & ** & ** & ** \\
\hline$A \times D$ & ** & ** & ** & ** & ** & ** \\
\hline $\mathrm{B} \times \mathrm{C}$ & ** & ** & ** & ** & ** & ** \\
\hline$B \times D$ & ** & ** & ** & ** & $\star \star$ & $\star * *$ \\
\hline$C \times D$ & ** & ** & ** & ** & ** & ** \\
\hline$A \times B \times C \times D$ & ** & ** & ** & ** & ** & ** \\
\hline
\end{tabular}




\section{El-Hamdi, Kh. H. et al.}

The highest values (1.558 and $1.587 \%)$ of $N,(0.277$ and $0.27 \%)$ of $P$ and $(2.291$ and $2.312 \%)$ of $\mathrm{K}$ as affected by organic manure obtained from fertilization at $10 \mathrm{~m}^{3}$ chicken manure fed.-1 in 2004 and 2005 seasons, respectively. These results indicate the essential role of organic manure for improvement of chemical and physical properties of the soil. Also, organic manure contains microorganisms which fix in and release phytohormones, which stimulate plant growth, N, P and K contents. These results could be enhanced with those obtained by Othman-Sanaa et al. (2005).

Data listed in Table 5 prove that $\mathrm{N}$ concentration in ear leaf of maize plants which fertilized with enciabeen (SRNF) increased by (5.78 and $0.14 \%)$ and $\mathrm{P}$ by $(7.69$ and $6.07 \%)$ in the $1^{\text {st }}$ and $2^{\text {nd }}$ seasons, respectively, compared fertilization at urea in the same seasons, whereas, $\mathrm{K}$ concentration in plants which fertilized with enciabeen increased by $0.77 \%$ in the $1^{\text {st }}$ season, while, fertilization with urea increased $\mathrm{K}$ content by $0.01 \%$ in the $2^{\text {nd }}$ season. The little increasing of $\mathrm{N}$ content in zea maize plants as affected of applying enciabeen compared urea may be due to depletion large amount of $\mathrm{N}$ from enciabeen applications by the last crop (tomato plants). But, these increasing of $\mathrm{N} \%$ may be due to that enciabeen applying may available regular source for $\mathrm{N}$ supply, and the leaching from enciabeen was less than urea. These results supported with those obtained by Abbady-Khadra et al. (2003) and El-Atawy (2007).

The highest values of $\mathrm{N}$ concentration (1.580 and $1.578 \%)$ and $(2.35$ and $2.353 \%$ ) of $\mathrm{K}$ in ear leaf as affected by $\mathrm{N}$ fertilizer levels in the $1^{\text {st }}$ and $2^{\text {nd }}$ seasons, respectively obtained from plants fertilized at $320 \mathrm{~kg} \mathrm{~N}$ fed. ${ }^{-1}$, while, the highest value of $\mathrm{P}$ concentration in the $1^{\text {st }}$ season $(0.282 \%)$ obtained from fertilization at $160 \mathrm{~kg} \mathrm{~N}$ fed. ${ }^{-1}$, and it was $(0.278 \%)$ in the $2^{\text {nd }}$ season, resulted from fertilization at $240 \mathrm{~kg} \mathrm{~N}$ fed.-1. The increment of NPK concentration in ear leaf may be due to higher availability of the nutrients with increase in the $\mathrm{N}$ fertilizer levels which final resulted in better root growth and increased physiological activity of roots to absorb the nutrients. These results are in accordance with those obtained by El-Atawy (2007) and OthmanSanaa et al. (2005).

\section{CONCLUSION}

From these results, it could be concluded that the application of irrigation water at 1.3 evaporation pan coefficient could be recommended with zea maize for high production under North Delta conditions. Addition of organic manure to the soils is an important practice in improving soil properties and productivity. Application of slow-release nitrogen fertilizers in sandy soils may available regular source for nitrogen supply and decreases leaching of nitrogen less than urea. 


\section{REFERENCES}

Abbady-Khadra A.; S.A.M. Hegab; M.S. Awaad; G.H. Abdel-Rehim and Faiza S. A. Salama (2003). Ureaform performance as a slow release fertilizer under sprinkler irrigation system. J. Agric. Sci. Mansoura Univ., 28 (11): 6969-6979.

Abdel-Mawly, S.E. and I. Zanouny (2005). Irrigation and Fertilization management for maximizing crop-water Effeciencies of Maize .Minia J. Agric. Res. And Develop. 25 (1):125-146.

Chapman ,H.D. and P.F. Pratt (1961). Methods of Analysis of soil Plant and Water. Univ. of Calif. Division of Agric. Sci. 60-69.

El-Atawy, Gh. Sh. I. (2007). Irrigation and fertilization management under the conditions of Kafr El-Sheikh Governorate soil Ph. D. Thesis, Fac. Agric., Mansoura Univ., Egypt.

El-Nagar, G.R. (2003). Integrating of mineral and Bio-fixed nitrogen fertilization in maize production under different irrigation regimes. Assiut J. Agric. sci.,34 (5) : 53-76.

Hanna, A.M. and T.I. El-Awag (2000). Effect of tillage treatments and farmyard manure application on some physical properties of the soil and maize production. J. Agric. Sci. Mansoura Univ., 25(2): 1127-1137.

Jackson, M.L. (1973)."Soil Chemical Analysis". Prentice-Hall Inc. Englewood Diffs. N. F.

Karam, F.; Breidy, J.; Rouphael, J. and Lahoud, R. (2002): Effect of water stress on the physiological behavior and yield of hybrid corn (cv. Manuel) in Lebanon. Cahiers-Agricultures 11(4), 285-291.

Mahdi, M. and X. Yin (2003). Effect of nitrogen rate, irrigation rate and plant population and corn yield and water use efficiency. Agron. J.,95: 14751482.

Murphy, J. and J.P. Riley (1962). A modified single solution method for the determination of phosphate in natural water. Anal. Chem. Acta., 27: 3136.

Nofal-Fatma A. E. and El-A. Mobarak (2003). Influence of maize hybrids under sandy soil condition. Egypt J. Sci., 18: 497-507.

Nofal-Fatma A. E., M. S. M. Soliman and M. M. Abdel-Ghani (2005). Effect of irrigation at different water depletions levels, nitrogen and manure applications on water use efficiency and maize grain yield in sandy soils. Monofiya J. Agric. Res. 30 (4):1159-1177.

Omran W. M. (2005). Maize yield response to available soil moisture. Monofiya J. Agric. Res. 30 (4): 1257-1268.

Othman-Sanaa A.; A. M. M. Shehata and I. M. El-Naggar (2005). Effect of rice straw compost and $\mathrm{N}$-fertilization on maize production and some soil physical properties. Minufiya J.Agric.Res. 30 (6): 1853-1863.

Page, A. L.; R. H. Miller and D. R. Keeny (1984). Methods of Soil Analysis. Madison, Wisconsin, USA, Part 2. 


\section{El-Hamdi, Kh. H. et al.}

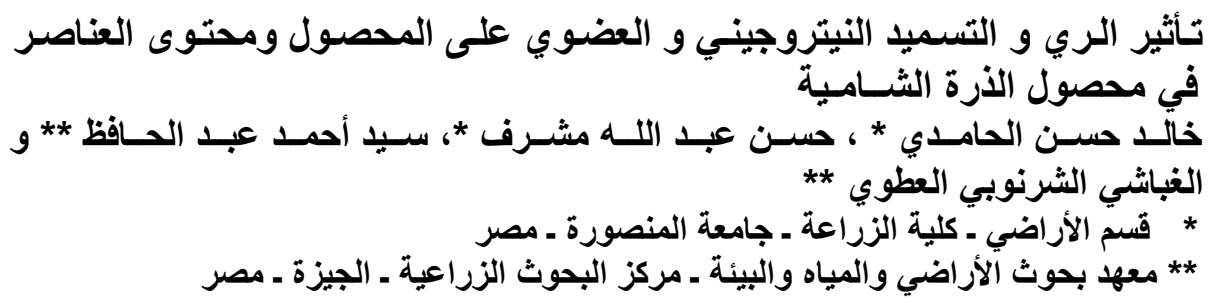

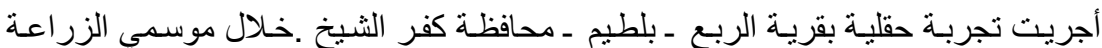

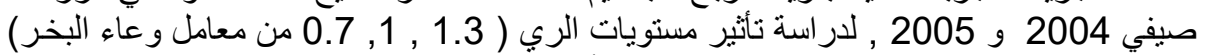

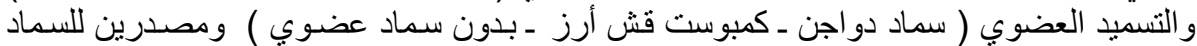

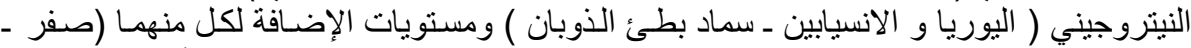

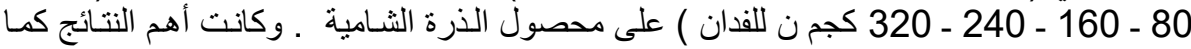

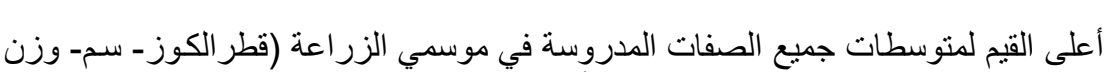
: يلي :

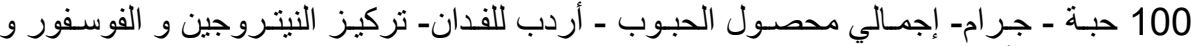

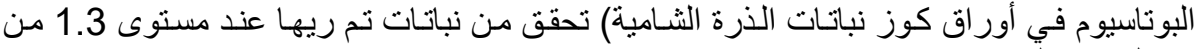

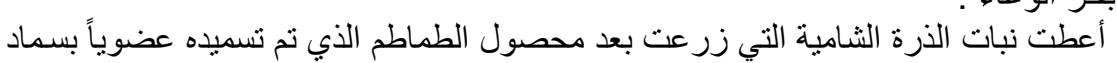

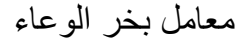

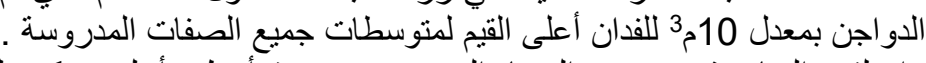

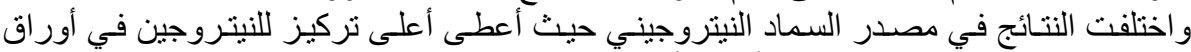

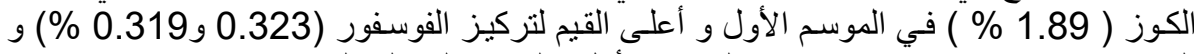

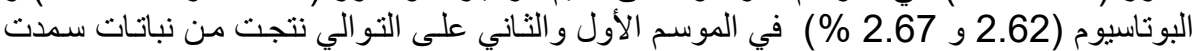

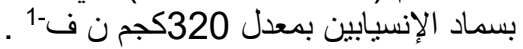

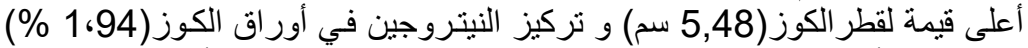

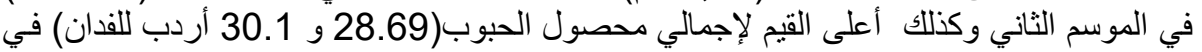

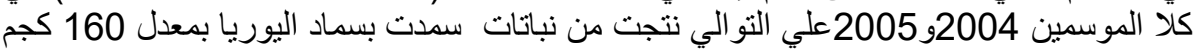

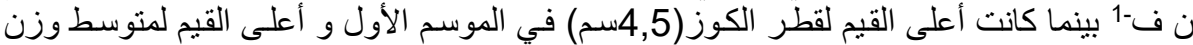

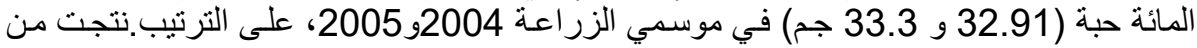

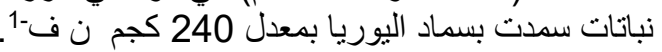

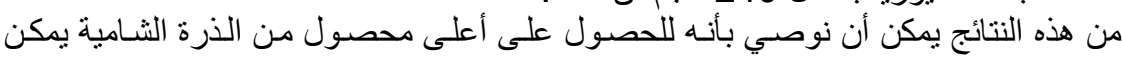

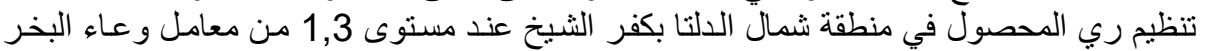

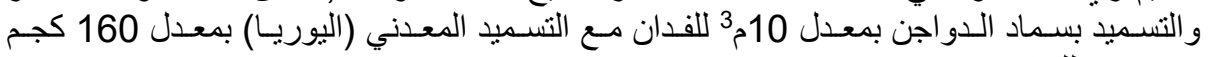

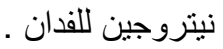

